\title{
Skilled and Creative Abilities of Elementary School Teacher Education Students at Faculty of Education of Universitas Negeri Malang on Creating Drawing Artworks
}

\author{
Sumanto \\ Elementary School Teacher Education \\ Department \\ Universitas Negeri Malang \\ Malang, Indonesia \\ sumantomunginan@gmail.com
}

\begin{abstract}
This research aims to describe skilled abilities on art techniques, creativity on drawing shapes, line composition, illustration and expression in the course of elementary school fine arts for Elementary School Teacher Education (PGSD) student. This research used the descriptive qualitative design. The research subjects consisted of 88 PGSD students at Campus 3 of State University of Malang, Blitar, East Java, Indonesia. The data was collected by documentation and appreciative observation. The data analysis used a descriptive qualitative content analysis approach and a drawing artworks analysis. The research result shows that: (1) the skilled abilities of drawing techniques in shapes, line composition, illustration, and expression show various sketch qualities on utilizing drawing tools and colours in accordance with their own preferences, (2) most of PGSD students have shown creative abilities on drawing artworks.
\end{abstract}

Keywords-creative and skilled ability, drawing of shape, line, illustration, expression

\section{INTRODUCTION}

Drawing is an art to visualize images from what a person or a draftsman feels, sees, wants and knows. Elementary School Teacher Education (PGSD) students consider drawing as a visualisation of their real life in tune with the competency and the skill in two-dimension fine arts. The presence of contacts with atmosphere and objects in the environment will produce ideas or initial concepts expressed in the form of fine artworks [1]. Each drawing art is a form of creative and appreciative abilities appealing to understand, appreciated as a universal visual language. In the course of elementary school fine artworks for PGSD students, the learning objective is that the students are able to draw line composition, shapes, illustration, word art, and expression. It is presumed that there is a variety of skilled and creative abilities of PGSD students of FIP UM on drawing, particularly at campus 3 Blitar which is appealing to be analysed into a research.

A person skilled ability in drawing has a relation to the ability of art techniques. It is the ability to implement a technique in creating every drawing according to types of preferred tools. The drawing artwork is a result of ideas, willingness, concepts and senses to the surrounding vicinity as a reflexion on both shapes and emotional encouragement to the environment [2]. A factor of psychological conditions while drawing cannot be ignored as well. The writer supports it basing on his own experience in guiding drawing activities in the fine art course in PGSD. The other factor is innate talent and experience in drawing.

Various types of drawing can be made from particular drawing tools by implementing the preferred technique of accomplishment. Generally, accomplishing a drawing is applied by thickening parts of drawing using tools until obtaining the impression of certain thickness and colours as well as textures. The variety of sketching techniques or colouring can be distinguished as shading, dussel, stippling, hard edge, combining and special techniques. The appearance of a drawing is presented using the free variation of composition made according to the selected theme of drawing.

In accordance with the course lesson plan of elementary school fine arts in the study program of PGSD, it presents the material about creating two-dimension fine arts, in the form of practical activities to create drawing arts. The creation of drawing must be made by the PGSD students comprises shapes, line composition, illustration, and expression. The shape drawing is in the form of creating drawing composition of cubical and cylinder objects in the space impression that can provide an appropriate impression to the object condition. The composition of line elements means the creation of composition or arrangement a number of shapes, sizes, colours of straight, curved, spiral and other lines providing the impression of objects such as humans, animals, plants and so on. Drawing illustration means creating images or pictures purposed to describe or illustrate certain phenomena (events, stories, imagination, etc); in the form of either single or serial drawings. The expression drawing means creating or making a drawing to express the beauty of an idea/ a concept, a natural object of the surrounding environment, and a creative imagination of the draftsman.

A study of various techniques of arts or accomplishing a drawing can be differentiated from characteristics of sketches, hard edges, or paints. They consist of shading, dussel, stippling, hard edge, and special techniques [3]. Shading is in the form of repetitive line sketches until obtaining particular impressions of thickness according to 
the shown object and space impression. Dussel is a technique of accomplishing a drawing by rubbing colouring pigments (powder) using the assistance of dusselar tools, rubbers until it is obtained fine and even thickness impressions. Stipple is a technique of drawing accomplishment applied in the form of dots sketching using drawing tools until getting certain impressions of thickness. The hard edge is in the form of water colouring (paint) sketching using the assistance of paintbrushes.

The existence of the elementary school fine arts course deals with the creative ability, the sensitivity, and the ability to express and appreciate beauty. The ability to create drawing arts is considered as aesthetic experience gained when a person observes or perceives objects of drawing, or it can be figured out as drawing objects having beautiful elements. The aesthetic experience (beauty) on students can result in the emergence of emotional reactions or responses to a person's beauty.

The research on PGSD students' abilities on creative drawing arts aims to describe: (1) the skilled abilities on art techniques, colouring objects, line composition, shapes, illustration and expression, (2) the tendency of creating the creative drawing in line composition, shapes, illustration and expression had by PGSD students. This research is conducted by several considerations: (1) students' drawing works is a form of diversity in students' aesthetic characters and creative behaviours, (2) information about the PGSD students' creative ability on two-dimension fine arts is one of the essential knowledge assets and cultures to explore and preserve, (3) the researcher has not found any research findings in relation to the study on college students' creative abilities on drawing.

\section{METHOD}

This research used the descriptive qualitative design to analyse the PGSD students' creative ability on drawing based on the fine arts approaches and characteristics in visualizing a drawing in both physical and aesthetic structures. According to Sachari [4], aesthetic approaches through art critiques means an art object can be observed through the expression, symbolic, social, cultural, beauty, economic, or religious meanings. In this term, every art object contains dimensions of dynamics, styles, techniques, aesthetic ideologies, lifestyle influences, and relationships between behaviours and environment. In accordance with the design, the data source for the research was obtained from documentation on PGSD students' drawings in Blitar.

The research subjects consisted of 88 PGSD students of Campus 3 taking the course of elementary school fine arts in even semester of academic year 2016/2017. The research procedures include: (1) providing individual drawing activities to PGSD students according to preferred types and techniques, (2) collecting documentation of PGSD students' drawings, (3) analysing and conducting data reduction, (4) presenting data in the form of tables and descriptive illustration to provide the meaning of data. The research finding is presented in the form of a descriptive report concerning the variety of themes/topics, titles, sources of ideas/concepts, and drawing objects in shapes, line composition, illustration, and expression.

The collection of data and information was analysed using a descriptive qualitative content analysis approach and an analysis of drawing artworks appreciation. The process of analysis included data reduction, display, and verification [5]. The data analysis was conducted in the analysis stage and data reduction. Data reduction is a process of reducing or discarding unnecessary data, focusing on, selecting and sharpening the collected data. According to Sumandyo [6], data reduction is purposed to do simplification, abstraction, and transformation of raw data from several field notes had been carried out since the initial data collection. The data display is intended to become a process of analysis to arrange the data findings into tables and descriptive explanation from general to the specific discussion in order to provide the meaning of data.

\section{RESULT AND DISCUSSION}

\section{A. Skilled abilities on Techniques of Drawing Shapes, Line Composition, Illustration and Expression}

In accordance with the fact concerning art techniques or ways to accomplish drawings created by PGSD students, it shows the presence of various quality conditions of art techniques or sketches in using drawing tools and colouring based on the students' preference. Most art techniques, colouring on every drawing composition of shapes, line composition, illustration and expression are very good and have the beautiful impression. The sketch of pencils, colouring pencils, crayons (pastel paints), oil pastels, waterbased paints, poster paints, drawing pen, markers are more dominant in every drawing work. The utilised pencils consist of $\mathrm{HB}$ and $\mathrm{B}(2 \mathrm{~B}, 3 \mathrm{~B}$ and $5 \mathrm{~B})$. The use of markers by students is generally limited to emphasise the object lines and small sized objects. The application of crayons uses some colouring brands such as Fabercastel, Titi, Kiko, Oil Pastel, dan Craypas. Particularly in drawing line composition, most of the students utilized Drawing Pen 02, and 05 .

The good performance of art techniques in accomplishing drawings is marked from the presence of impression of colouring qualities which is accurate, careful, neat, and harmonious from several elements of colours enabling it to present beautiful impression. The technique of drawing accomplishment can be considered perfect. The students' drawings present fine, smooth, impressive, natural, and expressive colouring scratches and have a good colour combination of monochromatic and contrast. Some of the drawing works have less beautiful colouring, less perfect, identified by lack accuration of using preferred drawing/colouring tools [7].

The inaccurate condition of colouring may be caused by several factors, such as (1) characteristics of drawing tools types the students used, like sharp, hard, medium, (2) characteristics of colouring they sense and see while sketching, whether it can cover the object area or surface well, if it has clear or transparent characteristics, and if it is difficult to apply, (3) the various condition of students' 
abilities, starting from very skilful in utilizing drawing tools to less skilful in drawing, (4) the students' emotional condition which may affect to the quality of the drawing work. The researcher thinks that the skilled ability of art techniques is not only influenced by the intelligence of having knowledge about how to draw well; but also influenced by less skilled, less creative, less dexterous, less focus and fewer patient conditions in utilizing drawing tools.

Specifically, the techniques of colouring on PGSD students' drawings comprise shading, dussel, linear, and hard edge. Shading is commonly applied to accomplish drawing works of shapes, line composition, illustration and expression. The use of pencils $\mathrm{HB}, 2 \mathrm{~B}, 3 \mathrm{~B}$ and $5 \mathrm{~B}$ results in the shading impression with particular thickness according to the desired object/shape impression. The shading forms the impression of parallel lines, thick to thin, or crossing combination lines forming the dark-light composition, spaces (three dimensions), and atmosphere expressed in the drawing. The utilisation of colouring pencils can produce the sketch of parallel lines, curve and other combination like the impression of line scratches from pencils. The benefit of utilizing colouring pencils is that it can give the shading impression from the combination of several same elements of colours on the coloured object. The use of drawing pens by students are much more identifies particularly in the drawing of line composition. In accordance with the characteristics of drawings, line composition truly demands skills of techniques to make scratches of diverse, various lines, in different sizes, thickness, length, in the form of straight, curve and other various creation of lines. The quality of beauty from the drawings of line composition is measured in terms of the emergence of the good impression in dynamic, rousing, full, firm, smooth and minimalist lines.

An example comes from an expression drawing which the idea is sourced from her own imagination with several references from Google. The title of her drawing is "Taman Impian". The main object is an area of a park, two people doing a selfie, and shops. The object is supported with the existence of trees, a bridge, flags, balloons, a Ferris wheel, and the impression of cloud which are accomplished using shading techniques combined with dussel techniques utilizing colouring pencils and drawing pens.

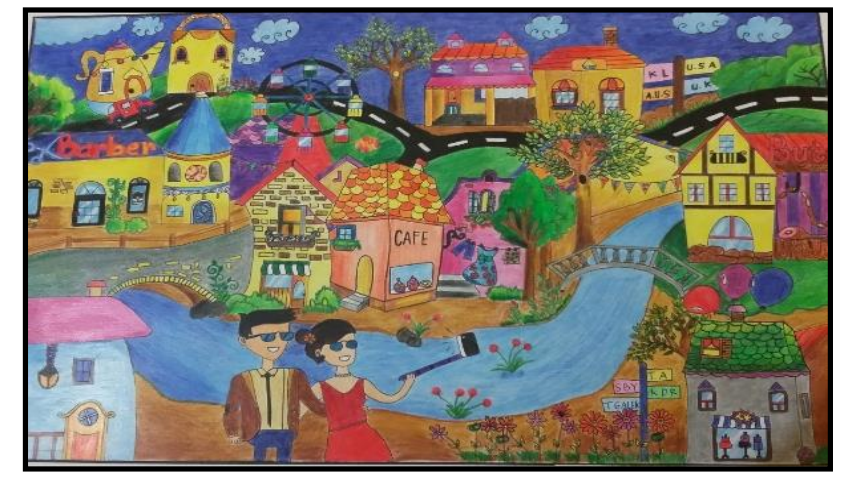

Fig 1. An expression drawing titled "Taman Impian"

Combining the shading technique with the dussel technique is also quite lots to use by students in accomplishing their drawings. The dussel technique is implemented by rubbing pigments/colours until it is obtained the impression of colours on an object, or fine/even composition of areas based on the preferred thickness. The types of drawing tools used in the dussel technique in the accomplishment of drawing shapes, illustration and expression consist of pencils, colouring pencils and crayons. However, it is identified that not all crayons used by students can be rubbed using the dussel technique due to the hardtype of crayons.

Linear techniques are most applied especially in the drawing of line composition. The characteristic of the linear technique is the presence of impressions on dominant line scratches in various characters matching with the size, shape, colour, direction, position and expressive or impressive impression shown by the lines. In fact, the drawing of line composition created by the PGSD students shows the dominant application of creatively linear techniques. Some creative impressions are seen from the creation of lines forming the impression of an object of animals, plants and others. The creative linear technique is also shown by the presence of diverse forms of lines involving beautiful characters in a composition unity. In addition, the creative impression is obtained from the precision on the selection of drawing tools and the consideration of colour thickness impressions.

The other colouring technique identified in the drawing works of the PGSD students is the hard edge technique applied using water-based paints and poster paints, although not many drawings are accomplished using both types of colouring tools. The hard-edge technique is applied by scratching colouring paste in a dilute enough composition and a bit dense using drawing paintbrushes. The drawing thickened using hard-edge techniques will gain the beautiful impression with specific characteristics of the existed colours. The colours have even, smooth, expressive, impressive, natural, transparent, thick impressions. The impression of transparent and impressive colouring is presented in the drawing accomplished using Waterferp. The colouring using poster paints will produce the impression of even and thick covering, as well as more variation of colours brightness.

The presence of skilled abilities in art techniques will create creative products in the form of various drawings enabling its existence to enjoy from the observation of physical and content (meaning) structures. The skilful drawing technique is marked by ideas/concepts, activities are realized into actions, and artefacts are in the form of masterpieces/objects. The quality of drawing techniques is determined by visual aspects, the existence of novelty of impressions in composition, originality, beauty, and artistic values. Generally, the characteristics of creative art are unique, beautiful, expressive, universal and individual.

\section{B. The Tendency of Creative Abilities on Creating Drawing Arts in the Forms of Shapes, Composition, Illustration and Expression by PGSD Students}

According to the data description in relation to the drawings of shapes, line composition, illustration, and expression, it is shown that there is a tendency on the creative ability to create drawing arts by PGSD students. The tendency of the creative ability of drawings is identified from three conditions consisting of: (1) every type of 
drawing works produced from various types of sources of ideas which are processed, created, adapted, and imitated is appropriate to the skilled ability of each student. The presence of contacts with the surrounding atmosphere and objects will produce initiate ideas or concepts which later is expressed in fine artworks [1]. (2) the composition of visual elements from every type of drawing works is made by considering the application of art procedures or principals, involving unity, balance, proportion, harmony, and accentuation, (3) there are diverse techniques of drawing accomplishment, both black-and-white and colourful impressions. Those three conditions strengthen the tendency of students' creative abilities in drawing according to the emergence of creative characteristics possessed by a person. The tendency of creative characteristics in drawing shapes, line composition, illustration, and expression is described as follows.

First, the presence of creative characteristics called "like to have imagination". In the drawing process, the PGSD students have shown potentials or creative thinking abilities and have acquired strength while imagining a work based on their own imagination. Having a process of creative imagination, it may have appeared an idea/ a concept which eventually can be determined a creation of objects visualised by drawings. The ability and creative thinking of the students to draw are as a form of art intelligence and the sharpness of beauty senses.

Second, the PGSD students have shown the creative characteristic of "the spirit to learn and try" to attain new experience, knowledge, and skills through individual activities in the drawing art. During the practical activity of drawing, it is identified that the presence of behaviours and expression of PGSD students strengthen their motivation to learn and keep trying to create a good and beautiful drawing with their own preferred type of drawings. The seriousness in the drawing is not only to achieve or gain rewards in good scores but also to express the behaviour of satisfaction, pleasure and happiness.

Third, the creative characteristic of PGSD students is marked by the existence of opportunities to "provide spare times for creation". Outside the course they get every week, the students also try to manage their times at both campus and house to make a drawing work. In this condition, the students use their times to focus on doing and accomplishing their drawings based on their own creative ideas. From the various drawings made by the PGSD students, it can be firmly stated that there are not the same drawings, yet it is more likely to strengthen the emergence of every type of drawings. Despite having the similar ideas, the same object, the same type of drawing tools, the meaning of visual structure composition is different from one another. Every drawing work has their own appeal and magnificent impression as well as art values.

Fourth, another creative characteristic is the ability of PGSD students to "express and create arts". The presence of potencies to express creative drawings will certainly not limit or inhibit the individual opportunity to express creative ideas, arrange drawings, selecting idea sources, and implement accomplishing techniques in every drawing. Furthermore, the abilities to express and create arts can be distributed through the selection of drawing media and art ways or techniques. The students are given freedom which is guided/ structured to determine their preferred drawing and colouring tools in accordance with their own condition.

Fifth, the other creative characteristic had by the PGSD students is the ability to become "an inventor" in creating drawing arts. In accordance with the level of creative quality visualized in the drawings of shapes, line composition, illustration, and expression, the finding shows that they are considered in the creative quality level of creating, adapting or modifying, and the lowest creativity level is imitating. Most of the students drawing works are in the form of the combination of adapted idea sources which are modified as their own creation and imagination. Some students also have the creativity level of creating. Nevertheless, some other creative abilities are just imitating the available drawing artworks, from both internet sources and books.

Sixth, concerning the presence of the creative characteristic to express, imagine, create arts, become inventors, have the motivation to learn and try, they show that the PGSD students have the competency of "creativity intelligence" in drawing activities. This is identified by the existence of abilities to relate one phenomenon, fact, example, an element of a figure or an object into a creation with a new composition or arrangement. The ability to connect ideas sourcing from the observation of natural objects, cultural objects, the real atmosphere of particular places and periods, interesting facts obtained from surrounding natural vicinity, events, experience and imagination carried out by each student.

The creativity intelligence is also comprehended as a process of creative thinking by looking at various sources/ objects to turn into a new idea. The process of combining various inspiration into a unity results in the variety and type of drawing works applied on A3 paper. The creativity intelligence in a person is certainly related to the vastness of knowledge (cognitive) and critical thinking abilities which can encourage the creativity on drawings. According to Wiliam [8], it is pointed out that the characteristics of cognitive creativity include: (1) the ability of fluent thinking (fluency), (2) the ability of lithe and flexible thinking (flexibility), (3) the ability to think originally (originality), (4) the ability of detailing (elaboration), and (5) the ability to evaluate (evaluation). In addition, the effective aspects (behaviours and senses) in an individual creativity comprise the curiosity, openness of new experience, and appreciation to the condition for present artworks.

The creative criteria mentioned by Shapiro [9] state that without the presence of clear creativity, the quality of a product of works is in a question. The criteria for creativity relate to the aspects of creative processes, persons, and products. The creative process is in charge to all stages in creating a drawing work (starting from planning, sketching, and accomplishing the drawings up to colouring as the final stage). Which is implemented independently without any assistance from others. The person mentioned in this condition is an individual or self-possessing the competency of thinking, sensing, and skills to be empowered in creating the drawing art. The creativity of "an individual" is more directed to a mental condition (psychology) forming 
creative personalities. According to Rachmawati [10], creativity is one of the behaviour characteristics showing intelligent behaviours, yet the creativity and intelligence do not always show satisfying correlation. In this relation, the students are willing and dare to express the originality of ideas/concepts and the problems they face during the process of creating drawing works.

Furthermore, the creative product is a factual and concrete manifestation in the form of drawing works (artefacts) which the existence can be enjoyed from the observation of both physical and content (meaning) structures. The drawing works of students generally show the characteristics which is: (1) expressive, reflected in the honesty of illustrating ideas of observation results in accordance with the students' point of views, (2) enhancing objects they consider essentials, (3) narrative, having relation to stories about themselves and environment, and (4) following the development pattern or period of the students' drawings [11]. In this term, the criteria of characteristics cannot be separated from three elements of cultures, consisting of (1) ideas/concepts, (2) activities as a concrete manifestation in actions, and (3) artefacts in the form of works/objects. The creative product in the form of drawings is determined in accordance with a number of visual aspects such as the presence of impressions in new composition, originality, beauty, and artistic values. The ability of intelligence and emotion supported by the technical skill of drawings will result in the creation of a creative drawing work. Generally, the characteristics of creative arts are unique, beautiful, expressive, universal and individual.

The example of creative illustration drawing is shown in the artwork below, the source of ideas is by observing the samples of illustration drawings on the internet. The main object is a spouse. The supporting objects include mountainous views, sky, and grass illustrated in the first drawing. The second drawing shows the supporting objects consisting of a house, a desk, a chicken and its chicks, grass and mountains. The third drawing shows the supporting objects comprising trees, slope, grass and offerings. The supporting objects in the fourth drawing are house wall and a chair.

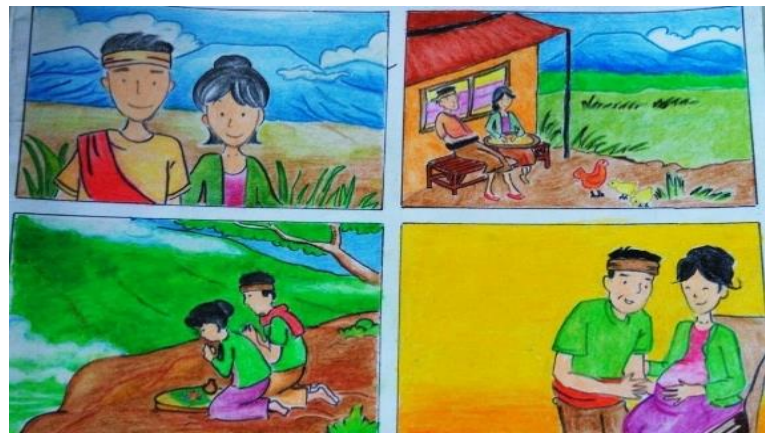

Fig 2. A creative illustration drawing

The story plot in the first picture tells about a spouse living in the middle of the forest. The second picture tells that spouse feels anxious like there is something lack in their life to live only the two of them in the forest. The third picture illustrates that they bring offerings to a sloping area to the God for granting their wish of having descendants. The last picture shows that the spouse pray is granted, the wife is pregnant, and the condition is welcomed in full of happiness by the spouse.

Looking at the meaning of the space aspect of the PGSD students' drawings, it can be stated that most of their drawings likely lead to the impression of space reduction, considering the perspective of drawing theories used by adult people. This is reasonable in which the factors of students' thinking intelligence and emotion is more influenced by concrete, real conditions associated with the objects illustrated in the drawing. Even so, this also does not inhibit the opportunity to express ideas into drawings based on the fictional potency and imagination which can be freely implemented. This is similar to the views that drawings as visual artworks, according to [12], have a function to deliver stories, comprehend ideas or feelings, embellish life with particular decoration. In addition, the space impression appearing in the drawing work is covering, the example is shown in the drawings of shapes, illustration and expression. Several drawing objects are presented in a composition which is overlapping and covering each other in positions, locations and sizes of the objects. The space impression which is unidentified in the PGSD students' drawings is birds' perspectives and laying down.

\section{CONCLUSION AND SUGGESTION}

\section{A. Conclusion}

First, the skills of art techniques/scratches on colouring in drawing shapes, line composition, illustration and expression created by the students show a various quality condition of art techniques or colouring scratches appropriating with the individual preference. Most the art techniques have good colour scratches on the media with very good composition and beautiful impression. The scratches of pencils, colouring pencils, crayons (pastel paints), oil pastels, water-based paints, poster paints, drawing pens and markers are dominant in every drawing work. Most students use pencils HB, 2B, 3B and 5B. The markers utilised by most students are generally limited to emphasise the borderline and small-sized objects. The students use various crayons brands consisting of Fabercastel, Titi, Kiko, Oil Pastel, and Craypas. Particularly in the line composition drawing, most students utilize Drawing Pen 02, and 05.

Second, most of PGSD students have shown creative abilities on drawing, considering several facts: (1) every drawing work is created from various sources of ideas processed, created, adapted, imitated according to individual skills and abilities, (2) the composition of visual elements on each drawing work is made considering the application of art procedures and principals, (3) there are diverse techniques in accomplishing drawings, both black-and-white and colourful. The creative ability in drawing is appropriate to the individual creative characteristics. The creative characteristics involve like to do imagination, have the motivation to learn and try, provide spare times to create 
works, express and create arts, have competencies in creative intelligence, have abilities to become inventors in creating drawing arts. Most of the students drawing works are from the combination of several sources of ideas which are adapted and modified in accordance with their own creation and imagination. Some students have the creative quality level in creating. Some others have creative abilities in imitating the present works, obtained from internet sources and books.

\section{B. Suggestion}

In accordance with the result of research, some suggestions are presented as a follow-up in future research and developing learning sources in the form of monograph stated as follows. (1) The research on the study of creative abilities on creating fine arts covers creating dwimatra and trimatra works in the course of elementary school fine arts, basing on the result of description in various types of works, art techniques, visual media and functions of fine artworks. (2) the research on the study of PGSD students' appreciative abilities on the beauty and aesthetics of fine artworks and crafts. (3) It is necessary to follow up by writing a monograph book as a reference concerning creating fine artworks particularly in the ability to create creative drawing arts.

\section{REFERENCES}

[1] Sumanto, Kajian Tema dan Obyek Gambar Anak-anak Sekolah Dasar, Jurnal Sekolah Dasar Tahun 23, No.1 Mei 2014, hal 1-11, Malang: Jurusan KSDP FIP UM, 2014.

[2] H. Pamadhi, Seni Keterampilan Anak, Jakarta: Penerbit UT, 2008.

[3] Sumanto, Pendidikan Senirupa di Sekolah Dasar, Malang: FIP UM, 2012.

[4] A. Sachari, Pengantar metodologi Penelitian Budaya Rupa. Jakarta: Penerbit Erlangga, 2004.

[5] N. T. Rokhmat, M. Rondhi, Profil Wanita dalam Karya Seni Reklame Visual. Semarang: Jurnal Imajinasi FBS UNNES, 2004.

[6] H. Sumandiyo, Seni dalam Rirual Agama, Yogyakarta: Pustaka, 2006.

[7] Sumanto, Pendidikan Senirupa di PGSD, Malang: FIP Universitas Negeri Malang, 2008.

[8] Munandar. Pengembangan Kreatifitas Anak Berbakat, Jakarta: Rineka Cipta, 1988 , p. 88.

[9] W. Djojonegoro, Kreativitas Kebudayaan dan Perkembangan IPTEK, Bandung: Alfabeta, 1994.

[10] Y. Rachmawati, Strategi Pengembangan Kreativitas Anak TK, Jakarta: Depdiknas Ditjen Dikti, Direktorat Ketenagaan, 2005, p. 22.

[11] S. Salam, Pendidikan Senirupa di Sekolah Dasar, Makasar: Universitas Negeri Makasar, 2001, p.33.

[12] M. Jazuli, Paradigma Kontekstual Pendidikan Seni, Surabaya: Unesa Press, 2008. 